\title{
Polskie ślady we współczesnym martyrologionie rosyjskim
}

\author{
Jarosław Charkiewicz \\ Warszawska Metropolia Prawosławna \\ Polska \\ jarek@cerkiew.pl
}

Jarosław Charkiewicz, Polish traces in the contemporary Russian martyrology, Elpis, 18 2016: 183-191.

\begin{abstract}
Russian Orthodox Church through its numerous organizations and unities, including the scientific ones, for many years gathered and published materials concerning people oppressed during the period of Soviet rule because of their faith. One of the new publications on the subject is edited in 2015 by the St Tikhon's Orthodox Humanities University in Moscow They Suffered Injustice for Christ's Sake. Persecutions of the Russian Orthodox Church 1917-1956. Bibliographical Guide. Book One. A. It contains information concerning several thousands of people with their names starting with letter "A". Amongst them there are names of nine persons connected with Poland, including three saints canonized by the Russian Orthodox Church. The article introduces us to their life and activity.

Streszczenie: Rosyjska Cerkiew Prawosławna, poprzez swoje liczne organizacje i jednostki, w tym naukowe, od lat gromadzi i publikuje materiały dotyczące osób represjonowanych z powodu wyznawanej wiary w okresie władzy radzieckiej. Jedną z nowych publikacji poświęconych temu tematowi jest wydana w 2015 r. przez Prawosławny Uniwersytet Humanistyczny św. Tichona w Moskwie książka pt. „Doznali krzywdy w imię Chrystusa. Prześladowania Rosyjskiej Cerkwi Prawosławnej. 1917-1956. Informator bibliograficzny. Księga pierwsza. A". Znajdują się w niej dane dotyczące kilku tysięcy osób noszących imiona (w przypadku mnichów czy hierarchów) lub nazwiska rozpoczynające się na literę „A”. Wśród nich znajdują się imiona dziewięciu osób związanych z Polską, w tym trzech świętych kanonizowanych przez Rosyjską Cerkiew Prawosławną. Artykuł niniejszy przybliża ich życie i działalność.
\end{abstract}

Keywords: Orthodoxy, Orthodox Church, Poland, saints, martyrs, oppressed.

Słowa kluczowe: Prawosławie, Cerkiew, Polska, święci, męczennicy, represjonowani.

Prawosławny Uniwersytet Humanistyczny św. Tichona w Moskwie od powstania w 1992 r. (jako Prawosławny Instytut Teologiczny św. Tichona ${ }^{1}$ ) za jeden z głównych celów swojej działalności obrał gromadzenie informacji na temat osób, które zginęły bądź były prześladowanie za wiarę prawosławną w okresie władzy radzieckiej. Informacje te, pochodzące z różnych archiwów, skrupulatnie opracowywano, tworząc m.in. elektroniczną bazę danych osób represjonowanych. W celu rozpowszechniania i popularyzacji wiedzy na temat prześladowań Cerkwi prawosławnej w Rosji Radzieckiej po 1917 r. powołano też do życia witrynę internetową, która jest rozbudowywana i aktualizowana o nowo pozyskiwane materiały ${ }^{2}$.

W ramach aktywnej i różnorodnej działalności wydawniczej uniwersytet ten wydał szereg książek i innego rodzaju publikacji w różnym stopniu związanych z tematyką martyrologiczną. W 2015 r. światło dzienne ujrzała ponad 700-stronicowa książka pt. „Doznali krzywdy w imię Chrystusa. Prześladowania Rosyjskiej Cerkwi Prawosław-

\footnotetext{
Podniesienie uczelni do rangi uniwersytetu i związana z tym zmiana nazwy z Православный Свято-Тихоновский богословский институт na Православный Свято-Тихоновский гуманитарный университет miały miejsce w 2004 roku.

2 База данных «За Христа пострадавшие»: http://kuz3.pstbi.ru/bin/ code.exe/frames/m/ind_oem.html/ans [dostęp: 04.04.2016]. W 1997 r., gdy baza ta ukazała się po raz pierwszy, znajdowało się w niej około 8 tys. nazwisk, w 2003 r. już ponad 20 tysięcy, a w 2008 r. około 30 tysięcy; patrz: За Христа пострадавиие. Гонения на Русскую Православную Церков. 1917-1956. Биограбический справочник, кн. I „A”, с. 21.
}

nej. 1917-1956. Informator bibliograficzny"3. W podtytule znajduje się adnotacja „Księga pierwsza” oraz litera „A”, co od razu wyraźnie wskazuje, że jest to pierwszy tom serii, dodajmy, z pewnością bardzo obszernej. Seria ta, chociaż nie dorówna objętością „Prawosławnej Encyklopedii”, wydawanej w Moskwie od 2000 roku $^{4}$, to i tak będzie zapewne liczyła kilkanaście tomów. Tym większe uznanie należy się wydawcy za podjęcie się tego wyjątkowego przedsięwzięcia.

Cała zaplanowana seria przypomina swojego rodzaju martyrologion ${ }^{5}$, tj. wykaz męczenników, których imiona zostały spisane $\mathrm{w}$ porządku kalendarzowym wraz $\mathrm{z}$ datą śmierci (równoznaczną z datą przejścia do nowego życia). Od klasycznego martyrologionu różni się jednak nie tylko innym (alfabetycznym, a nie kalendarzowym) porządkiem prezentowanych osób, ale i tym, że prezentuje osoby zarówno kanonizowane przez Cerkiew, jak i te, które do grona świętych nie zostały zaliczone. Nie nazwa gatunku literackiego jest tu jednak najistotniejsza. Wartość nadrzędną serii, co można ocenić na przykładzie pierwszego tomu, polega na sporządzeniu wykazu osób, które w obronie wiary doznały prześladowań, a często poniosły za nią śmierć, $\mathrm{z}$ reguły poprzez rozstrzelanie. Nie mniej ważne jest to, że owy wykaz osób wzbogacony jest o różnego rozmiaru dane

\footnotetext{
3а Христа пострадавщие..., dz.cyt., сc. 735.

4 Do dzisiaj wydano już jej 40 tomów.

5 Kościół rzymskokatolicki zasadniczo używa bardziej łacińskiego terminu „martyrologium”.
} 
biograficzne dotyczące każdej z nich, a w wielu przypadkach również ich fotografie.

$\mathrm{W}$ pierwszym tomie serii znajdują się dane dotyczace kilku tysięcy osób noszących imiona (w przypadku mnichów czy hierarchów) lub nazwiska rozpoczynające się na literę "A". Z punktu widzenia prawosławnego mieszkańca Polski istotne jest, że w ich gronie znajdują się również osoby związane $\mathrm{z}$ naszym krajem. Im to, a w pewnym wymiarze również ich pamięci, poświęcony jest niniejszy artykuł.

Po poddaniu analizie omawianej książki, uznać można, że z Polską związane są imiona dziewięciu wymienionych w pracy osób. Trzy z nich to święci kanonizowani przez Rosyjską Cerkiew Prawosławną, a pozostałe to osoby niekanonizowane. Wszyscy wymienieni to mężczyźni. Spośród trzech osób zaliczonych do grona świętych, a związanych $\mathrm{z}$ naszym krajem, jeden to biskup, jeden kapłan i jeden diakon. Przybliżmy ich życie i działalność.

Hierarchą, o którym mowa, jest biskup swijażski ${ }^{6}$ Ambroży (Gudko). Urodził się on, jako Bazyli Gudko, 28 grudnia 1867 r. w ówczesnej guberni lubelskiej Królestwa Polskiego. Dokładnego miejsca jego narodzin nie udało się ustalić. Rodzice chłopca wyróżniali się pobożnością i w duchu miłości do Cerkwi wychowywali też syna, a on od młodych lat pragnął zostać mnichem. W 1885 r. wstąpił do Chełmskiego Seminarium Duchownego, które ukończył w 1889 r. i jeszcze w tym samym roku rozpoczął naukę w Sankt Petersburskiej Akademii Teologicznej. W 1891 r., będąc jej studentem, złożył śluby monastyczne, otrzymując imię Ambroży. Kończąc uczelnię, 30 maja 1893 r., przyjął święcenia kapłańskie i jeszcze w tym samym roku został kierownikiem szkoły misyjnych katechetów na Ałtaju. W ten sposób z ziem położonych na zachodnich rubieżach Cesarstwa Rosyjskiego znalazł się niemal na jego drugim krańcu. Planowane było jego przeniesienie jeszcze dalej, bowiem w 1897 r. został mianowany kierownikiem nowo utworzonej Koreańskiej Misji Duchownej, jednak władze koreańskie nie zezwalały na wjazd na swoje terytorium nawet jednego prawosławnego duchownego. Stało się to możliwe dopiero w 1900 roku. Wcześniej, w 1899 r., archimandryta Ambroży został inspektorem Dońskiej Szkoły Duchownej, a dwa lata później rektorem mieszczącego się w Krzemieńcu Wołyńskiego Seminarium Duchownego. Powrócił więc niemal w rodzinne strony. Pełniąc tę funkcję napisał dwie większe prace. Pierwszą były rozważania na temat ideału życia chrześcijańskiego i środków jego osiągnięcia, a druga poświęcona św. Paisjuszowi Wieliczkowskiemu.

30 maja 1904 r. w soborze w Żytomierzu odbyła się jego chirotonia na biskupa krzemienieckiego, wikariusza Diecezji Wołyńskiej. Przewodniczył jej metropolita kijowski i halicki Flawian (Godorecki), a w chirotonii uczestniczyli też m.in.: biskup wołyński i żytomierski Antoni (Chrapowicki) oraz biskup lubelski Eulogiusz (Gieorgijewski). Również w tym okresie biskup nie stronił od pióra. Najpierw przelał na papier uwagi i przemyślenia ze swojej pierwszej podróży arcypasterskiej po Diecezji Wołyńskiej. Później napi-

\footnotetext{
Swijażsk (ros. Свияжск) - wieś w Rosji w Tatarstanie niedaleko Kazania.
}

sał pracę poświęconą działalności katechizacyjnej Cerkwi w szkole.

27 lutego 1909 r. Ambroży został mianowany biskupem bałtskim, wikariuszem Diecezji Krzemieniecko-Podolskiej, w 1914 r. został biskupem sarapulskim, wikariuszem Diecezji Wiatki, a 5 października 1916 r., w związku ze zmianami cerkiewnego podziału administracyjnego, biskupem sarapulskim i elabuskim. Pełniąc tę funkcję wiele wysiłku włożył w walkę z sektami i alkoholizmem.

Biskup Ambroży był utalentowanym i śmiałym oratorem, niestroniącym od wytykania ludzkich przywar. Równocześnie był człowiekiem prostym i otwartym, a przy tym bardzo zapalczywym, bez jakiejkolwiek bojaźni wypowiadającym swoje opinie na każdy temat. Dlatego też był bardzo lubiany przez wiernych. Nie stronił też od krytyki przywar władz administracyjnych miejscowej guberni, a w końcu 1916 r. za wypowiedzi antyreligijne na kilku socjalistów nałożył karę odłączenia od św. Eucharystii. Po przewrocie lutowym $1917 \mathrm{r}$. konflikt $\mathrm{z}$ władzą jeszcze bardziej przybrał na sile, co sprawiło, że w maja tegoż roku został przymusowo przeniesiony w stan spoczynku.

Po wybuchu rewolucji 1917 roku nagonka na biskupa przybrała na sile, ale on, nie obawiając się konsekwencji, nie szczędził słów krytyki wobec nowej władzy. W swych płomiennych kazaniach wzywał wiernych, aby nie ulegali agitacji ateistów-bolszewików. Nawoływał również do gorliwej modlitwy w intencji uwięzionego cara Mikołaja II i jego rodziny. 11 marca $1918 \mathrm{r}$. aresztowano go po raz pierwszy i, oskarżając o „działalność kontrrewolucyjną", postawiono przed sądem. Nie znajdując dowodów winy, po relacjonowanym $\mathrm{w}$ prasie procesie, wypuszczono go na wolność. 6 czerwca 1918 r. został ponownie aresztowany pod zarzutem tejże „działalności kontrrewolucyjnej”. Jednak i tym razem, po pięciu dniach, uniewinniono go i oswobodzono.

Bez obawy o swoje bezpieczeństwo hierarcha przeniósł się wówczas z Kazania do Swijażska. Tym, którzy mu to odradzali, odrzekł prosto i przekonująco: „Powinniśmy radować się, że Pan dał nam żyć w takich czasach, gdy możemy za Niego wycierpieć. Każdy z nas grzeszy przez całe życie, a cierpienie i wieniec męczeństwa odkupią wszystkie grzechy i uczynią wieczną szczęśliwość, której pozbawić nas nie mogą żadni czekiści". W tym czasie, a była to połowa lipca 1918 r., sprzyjający „białym” oddział Czechów pułkownika Kapella na sześć miesięcy zajął Kazań, a do Swijażska przybył sam Trocki. Najpierw uczynił miasto głównym punktem linii obrony, a następnie ofensywy. 8 sierpnia (27 lipca st.st.) do monasteru w Swijażsku przybyli czerwonogwardziści, aby zarekwirować zapasy zboża, lecz biskup Ambroży sprzeciwił się temu. Podobno na osobisty rozkaz Trockiego został aresztowany i odwieziony na stację kolejową w Swijażsku. Następnego dnia z rana, wraz z wiernym mu mnichem Hiobem, został odtransportowany do stacji Tiurlem, położonej na linii kolejowej Kazań-Moskwa. Tam wyprowadzono go z wagonu, gdzie był więziony, i na położonym nieopodal polu rozstrzelano.

3 października 1999 r. biskup Ambroży został zaliczony do grona świętych lokalnych Diecezji Kazańskiej. Jego 
ogólnocerkiewna kanonizacja miała miejsce 20 sierpniu 2000 roku. Cerkiew prawosławna czci pamięć świętego biskupa Ambrożego trzykrotnie: 27 lipca/9 sierpnia (w dniu śmierci), 4/17 października (w dniu święta Soboru Świętych Kazańskich) i w pierwszą niedzielę po 25 stycznia/7 lutego (w dniu święta Soboru Nowych Męczenników i Wyznawców Rosyjskich) ${ }^{7}$.

Kanonizowanym kapłanem, którego biogram znalazł się $\mathrm{w}$ omawianym informatorze-martyrologionie, miejscem swych narodzin związanym z Polską, jest św. kapłan-męczennik Aleksy Nikatow. Urodził się on w 1875 r. $\mathrm{w}$ Downarach ${ }^{8} \mathrm{w}$ rodzinie wiejskiego nauczyciela. Wkrótce po jego narodzinach rodzina Aleksego wyjechała do Rosji, gdzie rósł, uczył się i ukończył rok seminarium duchownego.

W latach 1899-1901 odbywał służbę wojskową, po powrocie ożenił się, a w 1905 r. został psalmistą cerkwi we wsi Kniażewo', ówczesnej guberni moskiewskiej. W następnym roku wraz z rodziną przeniósł się do położonej na południe od Możajska wsi Pietrowskoje i tam służył najpierw jako psalmista, później został wyświęcony na diakona, a w 1919 r. na kapłana. Wraz z małżonką doczekali się pięciorga dzieci - trzech synów i dwóch córek.

I wojna światowa i rewolucja 1917 r. zmusiły go do wyjazdu wraz z rodziną w głąb Rosji, w okolice Saratowa. Pozostając bez parafii pracował jako nauczyciel. Po powrocie do guberni moskiewskiej niósł posługę najpierw w cerkwi wsi Woskresienka na południe od Moskwy, a od 1923 r. w cerkwi Tychwińskiej wsi Ignatowo, na północ od stolicy Związku Radzieckiego. Będąc zasłużonym duchownym otrzymał szereg nagród cerkiewnych, w tym godność protojereja. Cieszył się dużym szacunkiem wiernych, o czym świadczyło to, że wiele osób z innych miast i wsi przyjeżdżało do niego $\mathrm{z}$ prośbą o poradę duchowną. Jako duchowny został w latach 20 . pozbawiony praw

Biogram na podstawie: 3a Христа пострадавщuе..., dz.cyt., s. 345347; J. Charkiewicz, Męczennicy XX wieku. Martyrologia Prawosławia w Polsce w biografiach świętych, wyd. II, Warszawa 2008, s. 39-48; J. Charkiewicz, Biskup-męczennik z Lubelszczyzny, „Cerkiewny Wiestnik” 2005, $\mathrm{nr}$ 1, s. 38-42; М. Польский, протопресв. Новые мученики Российские, Москва 1994, ч. 1, с. 178; ч. 2, с. 97-99; Мануил (Лемешевский В.В.), митр., Русские православные иерархи периода с 1893 по 1965 г2. (включительно), Erlangen 1979-1989, т. 1. с. 173-174; А. Журавский, Жизнеописание новых мучеников Казанских. Год 1918-й, Казань 1995, с. 31-54, 101; Состав Святейшего Правительствующего Синода и Российской иерковной иерархии на 1917 год, Петроград 1917, с. 230-231; Деяние Юбилейного Освященного Архиерейского Собора Русской Православной Церкви о соборном проставлении новомучеников и исповедников Российских XX века. Москва, 12-16 августа 2000 г.; Дамаскин (Орловский), игум., Амвросий (Гудко), епископ Свияжский, [в:] Православная энциклопедия, т. 2, Москва 2001, с. 137-138; Журналы заседания Священного Синода Украинской Правоставной Церкви от 20 июля 2012 года. Журнал 52, http://orthodox.org.ua/node/4549 [dostęp: 04.04.2016]; А.А.Бовкало, Выпускники Санкт-Петербургской Духовной Академии, http://petergen.com/bovkalo/duhov/spbda.html [dostęp: 04.04.2016]. Dane biograficzne postaci zaprezentowanych w niniejszym artykule zawarte w niektórych źródłach polskojęzycznych (np. www.wikipedia.pl) w wielu miejscach różnią się, niekiedy zasadniczo, od tych zawartych w źródłach rosyjskojęzycznych, które wydają się dokładniejsze. 8 Wieś położona ok. $10 \mathrm{~km}$ na północy zachód od Moniek na Białostocczyźnie.

9 Miejscowość położona ponad 100 km na zachód od Moskwy. wyborczych, pozbawiony zarekwirowanego przez władze gospodarstwa, dlatego też z trudem był w stanie wykarmić liczną rodzinę.

19 listopada 1937 r. został aresztowany pod zarzutem „działalności kontrrewolucyjnej, agitację mającą na celu niszczenie kołchozów, wstrętne oszczerstwa pod adresem władzy radzieckiej i nastroje terrorystyczne". Zamknięty $\mathrm{w}$ moskiewskim więzieniu na Tagance podczas przesłuchania nie przyznał się do zarzucanych mu przestępstw. 27 listopada 1937 r. został skazany na śmierć przez rozstrzelanie. Wyrok wykonano 3 grudnia 1937 r. na poligonie w Butowie pod Moskwą. Został zrehabilitowany 27 czerwca 1989 roku.

Rosyjska Cerkiew Prawosławna zaliczyła go do grona świętych 20 sierpnia 2000 roku. Jego pamięć Cerkiew prawosławna czci dwukrotnie: $w$ dniu śmierci - 20 listopada/3 grudnia oraz wraz z innymi męczennikami i wyznawcami rosyjskimi XX wieku - w pierwszą niedzielę po 25 stycznia/7 lutego ${ }^{10}$.

Wspomnianym wcześniej kanonizowanym diakonem związanym z Polską, którego wspomina omawiany informator, jest św. diakon-męczennik Aleksy Sienkiewicz. Urodził się on 15 marca 1875 r. w Jasionówce ${ }^{11}$, ówczesnej guberni grodzieńskiej. Brak jest bliższych informacji na temat jego dzieciństwa i młodości. Wiadomo jedynie, że pracował jako rachmistrz w banku państwowym z Grodnie, a później służył w carskiej armii, gdzie dosłużył się stopnia starszego podoficera.

W 1915 r. podczas bieżenstwa wraz z rodziną ewakuował się w głąb Rosji do obwodu moskiewskiego. Po zakończeniu rewolucji 1917 r. pracował w urzędzie zajmującym się organizowaniem powrotu $w$ rodzinne strony uciekinierów i jeńców wojennych z terenów Polski, Austro-Węgier i Niemiec. W 1923 r. sam zwrócił się do polskiej ambasady z prośbą o umożliwienie mu powrotu do Polski, jednak spotkała go odmowa.

W 1920 r. otrzymał on święcenia diakońskie i do 1929 r. służył bez większych przeszkód na terenie Diecezji Moskiewskiej. Wówczas został oskarżony o niepłacenie podatków (był to ówcześnie częsty zarzut kierowany przez władze pod adresem duchownych) i skazany na 5 lat więzienia. Po powrocie był diakonem najpierw cerkwi w Obuchowie pod Moskwą, a później we wsi Uspienskoje, na wschód od Moskwy. 26 listopada 1937 r. został aresztowany pod zarzutem „działalności kontrrewolucyjnej i szpiegostwa na rzecz Polski” i skazany na śmierć przez rozstrzelanie. Wyrok wykonano na poligonie Butowo pod Moskwą w dniu 11 grudnia 1937 roku. 19 lipca 1989 r. został zrehabilitowany.

Do grona świętych zaliczono go decyzją Świętego Soboru Biskupów Rosyjskiej Cerkwi Prawosławnej z 20

10 Biogram na podstawie: 3а Христа пострадавщuе..., dz.cyt., s. 285286; J. Charkiewicz, Męczennicy XX wieku..., dz.cyt., s. 116-117; Мартuролог расстрелянных и захороненных на полигоне НКВД „Объект Бутово" 08.08.1937-19.10.1938, Москва 1997, с. 245; Бутовский полигон. 1937-1938 г2. Книга памяти жертв политических репрессий, Выпуск 1, Москва 1997, с. 304; Деяние Юбилейного Освященного Архиерейского Собора..., dz.cyt.

11 Wieś położona około $30 \mathrm{~km}$ na północ od Białegostoku. 
sierpnia 2000 roku. Jego pamięć Cerkiew prawosławna czci dwukrotnie: w dniu śmierci - 28 listopada/11 grudnia oraz wraz z innymi męczennikami i wyznawcami rosyjskimi XX wieku - w pierwszą niedzielę po 25 stycznia/7 lutego ${ }^{12}$.

Przybliżywszy postacie trzech kanonizowanych związanych z Polską świętych, o których wspomina omawiana praca, przejść można do osób związanych z polskimi ziemiami, których biogramy znalazły się w informatorze, a którzy do grona świętych nie zostali zaliczeni. Według dokonanej analizy omawianego tomu, jest ich sześciu. Spośród nich dwaj to metropolici, a pozostali to arcybiskupi.

Metropolita Aleksy (Gromadzki) urodził się 1 listopada 1882 r. w Dokudowie ${ }^{13}$ jako Aleksander Gromadzki. Jego ojciec, Jakub, był cerkiewnym psalmistą pochodzenia ukraińskiego. W 1904 r. Aleksander ukończył Chełmskie Seminarium Duchowne, a w 1908 r. Kijowską Akademię Teologiczną. Podjął pracę nauczyciela religii w gimnazjum męskim w Chełmie. Ożenił się, a w lipcu 1908 r., w soborze Narodzenia Najświętszej Bogarodzicy w tym samym mieście, otrzymał święcenia kapłańskie. Został też duchownym tej świątyni i członkiem Chełmskiego Konsystorza Duchowego, a w 1916 r. diecezjalnym nadzorcą nad chełmskimi szkołami cerkiewnymi. W latach 1917-1918 niósł posługę w Kiszyniowie. W 1918 r. powrócił na Wołyń, gdzie został duchownym soboru Chrztu Pańskiego w Krzemieńcu i nauczycielem Krzemienieckiego Seminarium Duchownego. W latach 1921-1923 był rektorem tego seminarium. W styczniu 1922 r. został jednym z sekretarzy Soboru Biskupów powstającej samodzielnej Cerkwi prawosławnej w Polsce, popierającym metropolitę Jerzego (Jaroszewskiego), dążącego do jak najszybszego uzyskania przez tę Cerkiew autokefalii. 11 lutego 1922 r., po śmierci żony (wg innych źródeł, po uzyskaniu rozwodu), złożył śluby monastyczne, otrzymując imię Aleksy.

21 kwietnia (wg innych danych, 3 września) tego samego roku odbyła się jego chirotonia biskupia $\mathrm{z}$ tytułem biskupa łuckiego. Już 12 października bp Aleksy został przeniesiony na katedre grodzieńską, zajmując miejsce niesprzyjającego tendencjom proautokefalistycznym biskupa Włodzimierza (Tichonickiego). Diecezją Grodzieńską kierował przez niemal 12 lat, do 15 kwietnia 1934 roku. 10 lutego 1923 r., dwa dni po tragicznej śmierci metropolity Jerzego (Jaroszewskiego), został członkiem Synodu Cerkwi prawosławnej w Polsce. 1 grudnia 1924 r., już po wyborze arcybiskupa Dionizego (Waledyńskiego) na nowego metropolitę warszawskiego i całej Polski, zo-

\footnotetext{
12 Biogram na podstawie: 3а Христа пострадавщие..., dz.cyt., s. 301. J. Charkiewicz, Męczennicy XX wieku..., dz.cyt., s. 77-80; J. Charkiewicz, Śladami męczenników, św. męczennik Aleksy Sienkiewicz, „Wiadomości PAKP" 2007, nr 2, s. 18; Мартиролог расстрелянных и захороненных на полигоне НКВД „Объект Бутово”..., dz.cyt., с. 309; Деяние Юбилейного Освященного Архиерейского Собора..., dz.суt.; Синодик пострадавших за веру и Церковь Христову в Бутово, Москва 1995; Алексий Сенкевич, [в:] Православная энциклопедия, т. 1, Москва 2000, c. $652-653$.

13 Miejscowość, a obecnie wieś, w powiecie bialskim województwa lubelskiego, położona na południowym wschodzie od Białej Podlaskiej.
}

stał zastępcą przewodniczącego Rady Metropolitalnej przy zwierzchniku Cerkwi polskiej. W kwietniu i maju 1927 r. znajdował się w składzie delegacji osób towarzyszących metropolicie Dionizemu w podróży po Cerkwiach lokalnych Bliskiego Wschodu, co następnie obszernie opisał w wydanej książce. 3 lipca (lub czerwca) 1928 r. abp Aleksy został podniesiony do godności arcybiskupa, a w $1930 \mathrm{r}$. mianowano go członkiem komisji ds. przygotowań Soboru Lokalnego Polskiej Cerkwi Prawosławnej. 15 kwietnia 1934 r. został arcybiskupem wołyńskim i krzemienieckim. Historycy podkreślają, że w swojej posłudze był jednym z najbardziej aktywnych zwolenników ukrainizacji życia cerkiewnego wschodnich terenów Rzeczypospolitej. M.in. w 1937 r. w Diecezji Wołyńskiej zezwolił na sprawowanie nabożeństw po ukraińsku, z czego skorzystała około połowa parafii. W 1938 r., w okresie szeroko zakrojonej przez władze sanacyjne akcji burzenia prawosławnych świątyń na Chełmszczyźnie i południowym Podlasiu, dokonał objazdu diecezji, podczas którego wzywał do trwania przy wierze prawosławnej.

Jesienią 1939 r., po włączeniu zachodniej Ukrainy i zachodniej Białorusi do Związku Radzieckiego, został aresztowany przez władze radzieckie. W 1940 r. przeszedł pod jurysdykcję Patriarchatu Moskiewskiego, zachowując zarząd Diecezją Wołyńską. Po utworzeniu 28 października 1940 r. przez locum tenensa tronu patriarszego metropolitę Sergiusza (Stragorodzkiego) Egzarchatu Zachodniego, objął katedrę tarnopolsko-halicką (Diecezję Wołyńsko -Łucką powierzono arcybiskupowi Mikołajowi (Jaruszewiczowi)), w dalszym ciągu zamieszkując w Krzemieńcu. 25 marca 1941 r. został arcybiskupem rowieńskim i krzemienieckim. W czerwcu tego samego roku aresztowano go i wtrącono do więzienia $\mathrm{w}$ Tarnopolu, a następnie ( $\mathrm{w}$ obawie przed zbliżającym się frontem) wysłano konwojem na wschód. Udało mu się jednak uciec i powrócić do Krzemieńca.

18 sierpnia 1941 r. w Ławrze Poczajowskiej abp Aleksy zorganizował naradę biskupów, podczas której podjęto decyzję o reaktywacji statusu autonomii Ukraińskiej Cerkwi Prawosławnej w ramach Patriarchatu Moskiewskiego. Podczas kolejnej takiej narady, 25 listopada, został wybrany na egzarchę Ukrainy i podniesiony do godności metropolity. Intronizacja, z tytułem metropolity wołyńskiego i żytomierskiego, egzarchy Ukrainy odbyła się 9 grudnia tegoż roku. W tym okresie sytuację cerkiewną na Ukrainie skomplikowało powołanie do życia przez biskupa Polikarpa (Sikorskiego) Ukraińskiej Autokefalicznej Cerkwi Prawosławnej w 1942 roku. Dążąc do normalizacji życia cerkiewnego metropolita Aleksy w październiku 1942 r. podpisał akt o zjednoczeniu obu struktur, jednak w obliczu negatywnej oceny dokumentu ze strony podległych mu biskupów, wycofał swój podpis. Prawdopodobnie, właśnie to było bezpośrednią przyczyną jego zabójstwa przez banderowskich nacjonalistów w dniu 7 maja 1943 r. w okolicy wsi Smyga (między Łuckiem a Krzemieńcem) na Wołyniu, podczas wizytacji diecezji. Został pochowany w Krzemieńcu. Pozostawił po sobie szereg prac z zakresu historii i teologii. Historycy podkreślają również jego za- 
sługi dla prawosławnej działalności wydawniczej i dziennikarstwa ${ }^{14}$.

Metropolita Antoni (Chrapowicki), który część swojego życia związał z Wołyniem, to jeden $\mathrm{z}$ najbardziej znanych i ważnych hierarchów Rosyjskiej Cerkwi Prawosławnej przełomu XIX/XX i pierwszej połowy XX wieku. Urodził się on 17 marca 1863 r. we wsi Batagino, guberni nowogrodzkiej, w rodzinie szlacheckiej, jako Aleksy Chrapowicki. Dzieciństwo spędził w rodzinnej wsi oraz w Nowogrodzie. W duchu religijnym wychowywała go matka. Formował się pod dużym wpływem twórczości Fiodora Dostojewskiego i filozofii Władimira Sołowjowa. W 1881 r. ze złotym medalem ukończył gimnazjum w Sankt Petersburgu i rozpoczął studia w Akademii Teologicznej w tym samym mieście. Cztery lata później, jeszcze będąc studentem, 18 maja 1885 r. złożył śluby monastyczne przed rektorem uczelni, biskupem Arseniuszem (Briancewem), otrzymując imię Antoni. 12 czerwca tego samego roku otrzymał święcenia diakońskie, a 29 (lub 30) września kapłańskie. Po ukończeniu studiów pozostał na uczelni jako asystent inspektora i tzw. profesorski stypendysta. W roku szkolnym 1886/1887 wykładał homiletykę, liturgikę i prawo kanoniczne $\mathrm{w}$ seminarium duchownym w Chełmie, jednak w 1887 r., wraz z mianowaniem archim. Antoniego (Wadkowskiego) rektorem Sankt Petersburskiej Akademii Teologicznej, powrócił na swoją macierzystą uczelnię, gdzie został wykładowcą Starego Testamentu. W 1889 r. był już inspektorem uczelni, a rok później otrzymał godność archimandryty i został mianowany rektorem Sankt Petersburskiego Seminarium Duchownego. W 1891 r., w wieku zaledwie 27 lat, został rektorem Moskiewskiej Akademii Teologicznej. Kierował nią do 1895 r., gdy powierzono mu obowiązki rektora Kazańskiej Akademii Teologicznej.

7 września 1897 r. w soborze Objawienia Pańskiego w Kazaniu odbyła się chirotonia biskupia zaledwie 34-letniego archim. Antoniego. Przewodniczył jej arcybiskup ryski i mitawski Arseniusz (Brjancew). Został biskupem czeboksarskim, wikariuszem Diecezji Kazańskiej (w 1899 r. tytuł wikariusza zmienił się na biskupa czystopolskiego). Kijowską Akademią Teologiczną kierował do 1900 r., gdy mianowano go biskupem ufimskim i mienzelińskim, a dwa lata później - biskupem wołyńskim i żytomierskim.

Od tego czasu (w 1906 r. został podniesiony do godności arcybiskupa) prowadził aktywną działalność na rzecz propagowania Prawosławia na Wołyniu. Angażował się m.in. w zwalczanie katolicyzmu na terenie swojej diecezji, występując przeciwko małżeństwom mieszanym prawosławno-katolickim. W 1907 r. odbył podróż po Galicji i na Bukowinę, czyniąc obserwację, że wolność wyznania w Austro-Węgrzech jest pozorna, a prawosławni są poddawani

\footnotetext{
14 Biogram na podstawie: 3a Христа пострадавиuе..., dz.cyt., s. 270273; Акты Святейшего Тихона, Патриарха Московского и всея России, позднейшие документы и переписка о каноническом преемстве высшей иерковной власти, 1917-1943, Москва 1994, с. 755, 960; Мануил (Лемешевский В.В.), митр., Русские православные иерархи..., dz.cyt., т. 1, с. 112-113; В. Цыпин, прот., История Русской Церкви, 1917-1997, т. 9, Москва 1997, с. 225, 227, 230, 237, 260, 276, 277, 281-286, 720; Ю.А. Лабынцев, Алексий (Громадский Александр Якубович), [в:] Православная энииклопедия, т. 1, Москва 2000, с. 664-665.
}

prześladowaniom. Apelował również o zintensyfikowanie wysiłków na rzecz propagowania Prawosławia w Galicji. W 1913 r. zorganizował oddział Galicyjsko-Ruskiego Towarzystwa Dobroczynnego na Wołyniu i kierował jego pracami, osobiście uczestnicząc w rekrutacji unitów, którzy wyjeżdżali do rosyjskich seminariów duchownych, przyjmowali Prawosławie i wracali do Galicji. Szczególnie dużo uwagi przywiązywał do odrodzenia Ławry Poczajowskiej, m.in. inicjując budowę soboru Trójcy Świętej, będącej kopią takiej samej świątyni w Ławrze Troicko-Siergijewskiej. W latach 1906-1907 był jednym z przedstawicieli duchowieństwa w Radzie Państwa. W 1911 r. otrzymał tytuł profesora nauk teologicznych i został wyróżniony prawem noszenia brylantowego krzyża na kłobuku, a rok później wszedł w skład Świętego Synodu Rosyjskiej Cerkwi Prawosławnej.

14 maja 1914 r. mianowano go arcybiskupem charkowskim i achtyrskim. Po rewolucji lutowej 1917 r., 1 maja został pozbawiony katedry i odesłany do monasteru wałaamskiego. Jednak już w sierpniu tegoż roku na zgromadzeniu diecezjalnym został ponownie wybrany na arcybiskupa charkowskiego i achtyrskiego. Brał aktywny udział w Soborze Lokalnym Rosyjskiej Cerkwi Prawosławnej 1917-1918, będąc jednym $\mathrm{z}$ trzech kandydatów na patriarchę (uzyskał spośród nich największą liczbę głosów). 28 listopada 1917 r. został podniesiony do godności metropolity, a 30 maja 1918 r. wybrany na metropolitę kijowskiego i halickiego. Pod koniec tegoż roku został aresztowany i pół roku spędził w odosobnieniu. Po uwolnieniu powrócił do Kijowa stając po stronie Białych. W miarę ich klęsk, wyjechał do Grecji, na św. Górę Atos, a później do Konstantynopola, aby ostatecznie, w lutym 1921 r., osiąść w Sremskich Karlowcach w Serbii. Tam, w czerwcu 1923 r., został wybrany na zwierzchnika Rosyjskiej Cerkwi Prawosławnej za granicą. Kierował nią (zachował przy tym swój ostatni tytuł, tj. metropolity kijowskiego i halickiego) do śmierci 19 sierpnia 1936 roku. Ciało hierarchy spoczęło w kaplicy Iwerskiej ikony Matki Bożej w Belgradzie. Pozostawił po sobie dużo prac z różnych dziedzin teologii prawosławnej, historii Cerkwi i na tematy społeczno-polityczne ${ }^{15}$.

Kolejny z niekanonizowanych hierarchów, związany z Polską, to arcybiskup Arseniusz (Smoleniec). Urodził się on 21 lipca 1873 r. w Warszawie jako Aleksander Smoleniec. Pochodził z polskiej rodziny inteligenckiej. Został ochrzczony w obrządku rzymskokatolickim, jednak jeszcze w młodości przeszedł na Prawosławie. W 1896 r. ukończył studia prawnicze na Uniwersytecie Warszawskim. Następnie pracował w sądach w Twerze, Łomży i Warszawie. W 1900 r.

Biogram na podstawie: 3 а Христа пострадавщие..., dz.cyt., s. 526-532; Акты Святейшего Тихона..., dz.cyt., с. 840-841); Мануил (Лемешевский В.В.), митр., Русские православные иерархи..., dz.cyt., т. 1, с. 313-330; Биографические сведения о братии Киево-Печерской Лавры, пострадавшей за Православную веру в 20 столетии / Сост:: Л.П.Рылкова, Киев 2008, с. 17-25; Антоний (Храповицкий), митрополит Киевский и Галицкий, http://www.bogoslov.ru/persons/30369/index. html [dostęp: 04.04.2016]; Э.П.Р., Антоний (Храповицикий Алексей Павлович), [в:] Православная энциклопедия, т. 2, Москва 2001, с. 646-652; Fundamentalna praca poświęcona metropolicie Antoniemu: Епископ Никон (Рклицкий), Жизнеописание блаженнейшего Антония, митрополита Киевского и Галицкого, т. 1- 7, Нью-Йорк 1956- 1961. 
wstąpił od razu na drugi rok studiów Kazańskiej Akademii Teologicznej i już po dwóch latach ją ukończył. 23 marca 1902 r. przed rektorem uczelni, biskupem czystopolskim Aleksym (Mołczanowem), złożył śluby monastyczne w kaplicy akademickiej. W tym samym roku otrzymał święcenia diakońskie (31 marca) i kapłańskie (8 czerwca). Również w 1902 r. został nauczycielem seminarium duchownego w Kazaniu, jednak jeszcze w tym samym roku przeniesiono go do pracy w szkole duchownej w Klewaniu na Wołyniu. W 1903 r. został mnichem Ławry Kijowsko-Pieczerskiej i inspektorem seminarium duchownego w Kijowie. Dwa lata później podniesiono go do godności archimandryty i mianowano rektorem seminarium duchownego w Ardaniu (Osetia). W 1907 r. został przełożonym monasteru białynickiego w Diecezji Mohylewskiej na Białorusi.

22 października 1910 r. w Ławrze św. Aleksandra Newskiego w Sankt Petersburgu odbyła się jego chirotonia biskupia z tytułem biskupa piatigorskiego, wikariusze Diecezji Władykaukaskiej. Przewodniczył jej metropolita kijowski i halicki Flawian (Horodecki), a uczestniczył w niej m.in. przyszły patriarcha Tichon (Bieławin), będący wówczas arcybiskupem jarosławskim. Biskupowi Arseniuszowi powierzono też obowiązki przełożonego monasteru Nowy Atos w Abchazji. W 1912 r. został przeniesiony do Diecezji Twerskiej jako jej wikariusz z tytułem biskupa starickiego. Godność tę pełnił do 1917 r., gdy został biskupem priazowskim i taganroskim, wikariuszem Diecezji Jekatierynosławskiej. Uczestniczył w obradach Soboru Lokalnego Rosyjskiej Cerkwi Prawosławnej 1917-1918 roku. W 1918 r. powierzono mu tymczasowe kierownictwo Diecezją Rostowską. W maju 1919 r. wszedł w skład Tymczasowego Wyższego Zarządu Cerkiewnego na południowym wschodzie Rosji obejmującego obszary zajmowane przez wojska Białych pod dowództwem gen. Denikina. W maju 1919 r. został biskupem rostowskim i taganroskim. Po zdobyciu Rostowa przez bolszewików, w marcu 1922 r. aresztowano go, oskarżając o przeciwstawianie się konfiskacie majątku Rosyjskiej Cerkwi Prawosławnej. Został skazany na śmierć przez rozstrzelanie, jednak wyrok zamieniono na 10 lat zesłania. Ponad trzy lata spędził w łagrze urządzonym w dawnym monasterze sołowieckim. Po uwolnieniu, od października 1925 r. tymczasowo kierował Diecezją Saratowską, a w 1927 r. Diecezją Mińską. Jesienią tego roku na własną prośbę został przeniesiony w stan spoczynku, a 1 listopada podniesiony do godności arcybiskupa. Dwa tygodnie później był już arcybiskupem stalingradzkim, a od 1930 r. arcybiskupem krymskim. W 1931 r. przeniesiono go do Diecezji Orłowskiej i Siewskiej, jednak nie mógł przystąpić do wypełniania swych obowiązków. W kolejnym roku ponownie został przeniesiony w stan spoczynku. W 1933 r. hierarchę aresztowano i skazano na zesłanie, które odbywał w kilku miejscach. Gdy przebywał na zasłaniu, w 1935 r. został mianowany arcybiskupem semipałatyńskim, jednak i tym razem, ze względu na stan zdrowia, nie mógł przystąpić do wypełniania swych obowiązków. Zmarł, prawdopodobnie, na zasłaniu 19 lutego 1937 roku. Według innych danych, miało to miejsce w 1940 lub 1941 roku. Został pochowany w Taganrogu (województwo rostowskie).
We wspomnieniach osób, które znały arcybiskupa Artemiusza, był on człowiekiem bezkompromisowym w kwestiach wiary, a w ludziach najbardziej cenił prawdomówność. Nabożeństwa sprawował uroczyście, chociaż z pokorą. Od 1917 r. prowadził dzienniki, które jednak nie zachowały się. Miał umysł wybitnie ścisły i świetną pamięć. Znał wiele języków, w tym polski, rosyjski, angielski, francuski, niemiecki, włoski, grekę, łacinę i hebrajski ${ }^{16}$.

Następny niekanonizowany hierarcha, imię którego odnotowano w omawianej pracy, to arcybiskup Antoni (Marcenko). Większość swojego dorosłego życia związał z Prawosławiem w Polsce. Urodził się, jako Aleksander Marcenko, 12 marca 1887 r. w Odessie. W 1910 r. ukończył Odeskie Seminarium Duchowne, a w 1914 r. Sankt Petersburską Akademię Teologiczną. Dwa lata przed jej ukończeniem, 20 lipca 1912 r., przed przyszłym pierwszym metropolitą warszawskim i całej Polski Jerzym (Jaroszewskim), a ówczesnym biskupem kałuskim i borowskim, złożył śluby monastyczne, a dzień później, również z rąk tego hierarchy, otrzymał święcenia diakońskie. Poprzez misję w Persji, krótki pobyt w pustelni glińskiej, okres nauczania w Stawropolskim Seminarium Duchownym i w 1920 r. emigrację do Serbii, w lipcu $1922 \mathrm{r}$. na prośbę metropolity Jerzego (Jaroszewskiego) przybył do Polski.

Cerkwią w Polsce kierował wówczas, od blisko dwóch lat, właśnie metropolita Jerzy, który wraz z synodem biskupów podjął już decyzję o zwróceniu się do Patriarchatu Konstantynopolitańskiego z prośbą o przyznanie autokefalii. Archimandryta Antoni został mianowany proboszczem głównej świątyni prawosławnej w Polsce - soboru św. Aleksandra Newskiego. Został też przewodniczącym Warszawskiego Konsystorza Duchowego. Jednak już w październiku 1922 r. przejechał do Wilna, zostając tam administratorem Diecezji Wileńskiej, przewodniczącym Wileńskiego Konsystorza Duchowego i przełożonym monasteru Świętego Ducha w tym mieście.

25 lutego 1923 r., po uzyskaniu zgody polskiego rządu, archim. Antoni otrzymał święcenia biskupie. Chirotonii w warszawskim soborze św. Aleksandra Newskiego przewodniczył arcybiskup wołyński i krzemieniecki Dionizy (Waledyński). Było to tuż po upłynięciu 40 dni od tragicznej śmierci metropolity Jerzego. Nowy biskup otrzymał tytuł biskupa lubelskiego, wikariusza Diecezji Warszawsko -Chełmskiej. Z zadowoleniem przyjął on decyzję patriarchy konstantynopolitańskiego Grzegorza VII o przyznaniu Cerkwi prawosławnej w Polsce autokefalii. W 1924 r. bp Antoni został rektorem Wileńskiego Seminarium Duchownego, a dwa lata później Wołyńskiego Seminarium Duchownego. Jeszcze w tym samym $1926 \mathrm{r}$. został jednak zwolniony $\mathrm{z}$ tej funkcji, a powodem ku temu był jego sprzeciw wobec polonizacji prawosławnych szkół teologicznych w Polsce.

Biogram na podstawie: За Христа пострадавшие..., dz.cyt., s. 604606; Акты Святейшего Тихона..., dz.cyt., с. 237, 842, 964; Мануил (Лемешевский В.В.), митр., Русские православнье иерархи..., т. 1, с. 386-389; И. Резникова, Православие на Соловках: Материалы по истории Соловецкого лагеря, Санкт-Петербург 1994, с. 115-116; Владислав Цыпин, прот., Арсений (Смоленеи, Александр Владиславович), [в:] Православная энциклопедия, т. 3, Москва 2002, с. 408-409. 
W 1928 r. bp Antoni, w związku z poparciem, jakiego udzielił ruchowi w Cerkwi na rzecz jej ukrainizacji, został przeniesiony w stan spoczynku. Zamieszkał wówczas w męskim monasterze św. Mikołaja w Mielcach (obecnie w obwodzie wołyńskim). W marcu 1930 r. powrócił z przymusowego pobytu w monasterze i został mianowany biskupem kamieńsko-kaszyrskim, wikariuszem Diecezji Pińsko-Poleskiej, a rok później złożył przysięgę na wierność państwu polskiemu. Od kwietnia 1934 r. do września 1937 r. administrował Diecezją Grodzieńską jako jej locum tenens. Wówczas ponownie został zesłany do monasteru, jednak zachował swój wcześniejszy tytuł biskupa kamieńsko-kaszyrskiego.

Podczas II wojny światowej, 25 czerwca 1940 r., bp Antoni złożył przed arcybiskupem Mikołajem (Jaruszewiczem) akt pokutny i ponownie został duchownym Rosyjskiej Cerkwi Prawosławnej. Jeszcze w tym samym roku, 28 października, mianowano go wikariuszem diecezji wołyńskiej z zachowaniem wcześniejszego tytułu. 28 marca 1941 r. został podniesiony do godności arcybiskupa. 18 sierpnia 1941 r. uczestniczył w odbywającym się w Ławrze Poczajowskiej naradzie prawosławnych biskupów Ukrainy, a 4 dni później został skierowany na katedrę chersońską i odeską, na której pozostawał do marca 1944 roku. Przez Rumunię udał się wówczas do Czechosłowacji, gdzie służył w cerkwi świętych Piotra i Pawła w Karlowych Warach, od 19 października 1945 r. zostając oficjalnie p.o. proboszcza. Następnie wrócił do Rosji, gdzie ponownie został przyjęty do Rosyjskiej Cerkwi Prawosławnej. 17 stycznia 1946 r. został arcybiskupem orłowskim i briańskim, zaś 19 lipca tego samego roku objął równocześnie katedrę tulską i bielowską.

3 grudnia 1951 r. abp Antoni został aresztowany, a 5 czerwca 1952 r. za „zdradę ojczyzny” skazany na 25 lat łagru. Wcześniej, 1 kwietnia 1952 r., zwolniono go z obowiązku kierowania diecezją. Dalsze jego losy nie są znane. Prawdopodobnie zmarł na zesłaniu w grudniu $1954 \mathrm{r}$. w obwodzie irkuckim. Decyzją z 4 września 1992 r. został zrehabilitowany ${ }^{17}$.

Omawiany informator-martyrologion zawiera imiona jeszcze dwóch niekanonizowanych hierarchów, w życiu których znalazły się epizody związane z polskimi monasterami.

$\mathrm{Z}$ monasterem supraskim związany jest arcybiskup iżewski ${ }^{18}$ Abrahamiusz (Diernow). Urodził się on, jako Anatol Diernow, 29 lipca 1874 r. we wsi Wierchnije Parzi (obecnie obwód kirowski, pn. wsch. od Moskwy). Po ukończeniu seminarium duchownego we Wiatce (1897) i Kazańskiej Akademii Teologicznej (1901) złożył śluby monastyczne oraz otrzymał święcenia diakońskie i kapłańskie (1901). 4 kwietnia 1911 r. został przełożonym monasteru

\footnotetext{
17 Biogram na podstawie: За Христа пострадавщuе..., dz.cyt., s. 518519; Феодор Кривонос, свящ., Буевский А.С., Антоний (Мариенко Александр Франиевич), [в:] Православная энииклопедия, т. 2, Москва 2001, с. 631; Акты Святейшего Тихона..., dz.cyt., с. 963; Религиозные деятели и писатели русского зарубежья, http://zarubezhje.narod.ru/ av/a_052.htm [dostęp: 04.04.2016]; Мануил (Лемешевский В.В.), митр., Русские православные иерархи..., dz.суt., т. 1, с. 292-293. „ЖМП” 1945, № 11, c. 18.

18 Iżewsk - miasto w europejskiej części Rosji, położone pomiędzy Wołgą a Uralem.
}

supraskiego, otrzymując godność archimandryty. Kierował nim do 1917 r., kiedy został przeniesiony do Ławry św. Aleksandra Newskiego w Piotrogrodzie (wcześniej i obecnie Sankt Petersburg). 3 września 1923 r. odbyła się jego chirotonia biskupia. Otrzymał tytuł biskupa urżumskiego, wikariusza Diecezji Wiackiej. Pod koniec tego roku został aresztowany. Niemal pięć lat spędził na zesłaniu na Syberii. Po powrocie najpierw kierował Diecezją Głazowską ${ }^{19}$, a 7 stycznia 1937 r. objął Diecezję Iżewską i został podniesiony do godności arcybiskupa. Cztery miesiące później aresztowano go pod zarzutem „agitacji antyradzieckiej”, wtrącono do więzienia i skazano na 10 lat pozbawienia wolności. Zmarł w 1939 r. (dokładna data nie jest znana) podczas transportu do łagru ${ }^{20}$.

Z kolei z monasterem św. Onufrego w Jabłecznej związane jest imię innego hierarchy represjonowanego przez władze radzieckie. To arcybiskup nowotorski ${ }^{21}$ Agapit (Borzakowski). Urodził się on w 1860 r. we wsi Ostapowka ówczesnej guberni połtawskiej. Ukończył Wydział Medycyny na Uniwersytecie Moskiewskim i przez 25 lat w guberni włodzimierskiej pracował jako lekarz. Postanowił jednak diametralnie zmienić swoje życie: złożył śluby monastyczne. W 1909 r. został mnichem monasteru jabłeczyńskiego, znajdującego się podówczas w Diecezji Chełmskiej. Tam też otrzymał święcenia kapłańskie i zamieszkiwał do 1914 roku. Wówczas został kapelanów wojskowym i niósł posługę na froncie północnym koło Rygi. Po zakończeniu I wojny światowej, w 1918 r., został przełożonym monasteru św. Mikołaja we wsi Ordyno w guberni briańskieje2, którym kierował do 1921 roku. 12 grudnia 1921 r. odbyła się jego chirotonia biskupia. Został wówczas biskupem dmitriewskim, wikariuszem Diecezji Orłowskiej²3 dwa lata później biskupem orłowskim, a w 1924 r. biskupem briańskim. Jeszcze w tym samym roku aresztowano go i zesłano do guberni twerskiej. Do Briańska wrócił w 1927 r., skąd w 1929 r. wyjechał do Orła. W 1930 r. został biskupem starodubskim $^{24}$, lecz wkrótce aresztowany pod zarzutem „organizowania w Briańsku i Koraczewie komórek monastycznych o charakterze antyradzieckim, mającym na celu obalenie władzy radzieckiej”. Skazano go na 10 lat łagru i zesłano na Syberię, skąd został zwolniony pod koniec 1933 roku. Został wówczas biskupem nowotorskim, wikariuszem Diecezji Kalinińskiej ${ }^{25}$, a w kolejnym roku podniesiony

\footnotetext{
19 Głazow - miasto położone $180 \mathrm{~km}$ od Iżewska.

20 Biogram na podstawie: За Христа пострадавшие..., dz.cyt., s. 66-67. Szerzej patrz: Мануил (Лемешевский В.В.), митр., Русские православные иерархи..., dz.суt., т. 1, с. 25; Акты Святейшего Тихона..., dz.суt., c. 924, 927, 952, 957; Дамаскин (Орловский), игум., Шумилов Е.Ф., Авраамий (Дернов Анатолий Иванович), [в:] Православная энциклопедия, т. 1, Москва 2000, с. 169; Шумилов Е.Ф., Православная Удмуртия: История Ижевской и Удмуртской епархии, ХХ в., Ижевск 1996.

21 Nazwa od miasta Torżok, położnego w Rosji w obwodzie twerskim, znajdującym się między Moskwą a Sankt Petersburgiem.

22 Briańsk (ros. Брянск) - miasto w zachodniej Rosji, w pobliżu granicy z Białorusią i Ukrainą.

23 Od miasta Orzeł (ros. Орёл) - miasto w Rosji, położone ok. 350 km na pd. zach. od Moskwy.

24 Starodub (ros. Стародуб) - miasto na terenie obwodu briańskiego.

25 Kalinin (ros. Калинин) - do 1934 r. Wiatka - miasto położone w północno-wschodniej europejskiej części Rosji.
} 
do godności arcybiskupa. 27 sierpnia 1936 r. ponownie aresztowano go, a po dwóch miesiącach skazano na pięć lat zesłania za „udział w grupie kontrrewolucyjnej”. Wysłano go do Kazachstanu, gdzie ponownie został aresztowany i skazany za „organizowanie grupy kontrrewolucyjnej” na śmierć przez rozstrzelanie. Wyrok wykonano 28 listopada 1937 roku. W 1989 r. został zrehabilitowany ${ }^{26}$.

Mniej lub bardziej obszerne opisy życia kanonizowanych i niekanonizowanych postaci, w różnym stopniu

\footnotetext{
26 Biogram na podstawie: 3a Христа пострадавшие..., dz.cyt., s. 75-76; Мануил (Лемешевский В.В.), митр., Русские православные иерархи..., dz.cyt., т. 1, с. 29; Акты Святейшего Тихона..., dz.cyt., с. 915, 921, 926, 937, 948, 957-958. Ермаков П.Ю., Агапит (Борзаковский Антоний Иосифович), [в:] Православная энииклопедия, т. 1, Москва 2000, с. 226-227; К пятилетию архипастырского служения преосвященнейшего Агапита, епископа Екатеринославского и Мариупольского, в Екатеринославской епархии, Екатеринослав 1916; Мануил (Лемешевский В.В.), митр., Русские православные иерархи..., dz.суt., т. 1, с. 31; 3а Христа пострадавшие, кн. 1, с. 31-32.
}

związanych z Polską, nie zostały w niniejszym artykule zaprezentowane przypadkowo. Zasługują one bowiem na pamięć nam współczesnych jako osób, które pozostawiły trwały ślad w dziejach Cerkwi prawosławnej w Polsce, niejednokrotnie swym życiem dając przykład trwania w wierze. Nieustanne odświeżenie pamięci wybitnych, mniej i bardziej znanych osób związanych z Prawosławiem w Polsce, wydaje się ważnym obowiązkiem współczesnych, jako że ich pamięć nie może odejść w zapomnienie.

Nie bez znaczenia wydaje się przytoczenie szczegółów z życia prezentowanych postaci właśnie w języku polskim. O ile po rosyjsku są one dostępne w wielu publikacjach i w internecie, to w świecie polskojęzycznym jest ich znacznie mniej, a jeśli są (np. w internecie), to zawierają niemało pomyłek, a niekiedy również stronniczych wniosków.

Należy żywić nadzieję, że kolejne tomy prezentowanego dzieła będą ukazywały się regularnie i nieustannie wzbogacały naszą wiedzę o przodkach, którzy wycierpieli i oddali swoje życie za Chrystusa.

\section{Bibliografia}

J. Charkiewicz, Biskup-męczennik z Lubelszczyzny, „Cerkiewny Wiestnik" 2005, nr 1, s. 38-42.

J. Charkiewicz, Męczennicy XX wieku. Martyrologia Prawosławia $w$ Polsce w biografiach świętych, wyd. II, Warszawa 2008.

J. Charkiewicz, Śladami męczenników, św. męczennik Aleksy Sienkiewicz, „Wiadomości PAKP” 2007, nr 2, s. 18.

Акты Святейтего Тихона, Патриарха Московского и всея России, позднейшие документы и переписка о каноническом преемстве высшей церковной власти, 1917-1943, Москва 1994.

Алексий Сенкевич, [в:] Православная эничиклопедия, т. 1, Москва 2000, с. 652-653.

Антоний (Мариенко Александр Францевич), [в:] Православная энциклопедия, т. 2, Москва 2001, с. 631.

Антоний (Храповиикий), митрополит Киевский и Галицкий, http://www.bogoslov.ru/persons/30369/index.html [dostęp: 04.04.2016].

База данных «За Христа пострадавшие»: http://kuz3.pstbi.ru/ bin/code.exe/frames/m/ind_oem.html/ans [dostęp: 04.04.2016].

Биографические сведения о братии Киево-Печерской Лаврь, пострадавшей за Православную веру в 20 столетии / Сост.: Л.П.Рылкова, Киев 2008.

А. А. Бовкало, Выпускники Санкт-Петербургской Духовной Академии, http://petergen.com/bovkalo/duhov/spbda.html [dostęp: 04.04.2016].

Бутовский полигон. 1937-1938 г2. Книга памяти жертв политических репрессий, Выпуск 1, Москва 1997.

Дамаскин (Орловский), игум., Амвросий (Гудко), епископ Свияжский, [в:] Православная энциклопедия, т. 2, Москва 2001, с. 137-138.
Дамаскин (Орловский), игум., Шумилов Е.Ф., Авраамий (Дернов Анатолий Иванович), [в:] Православная энииклопедия, т. 1, Москва 2000, с. 169.

Деяние Юбилейного Освященного Архиерейского Собора Русской Православной Церкви о соборном прославлении новомучеников и исповедников Российских ХХ века. Москва, 12-16 августа 2000 г.

А. Журавский, Жизнеописание новых мучеников Казанских. Год 1918-й, Казань 1995.

Журналы заседания Священного Синода Украинской Православной Церкви от 20 июля 2012 года. Журнал 52, http:// orthodox.org.ua/node/4549 [dostęp: 04.04.2016].

За Христа пострадавшие. Гонения на Русскую Православную Церков. 1917-1956. Биограбический справочник, кн. I „А”, c. 21.

Епископ Никон (Рклицкий), Жизнеописание блаженнейщего Антония, митрополита Киевского и Галицкого, т. 1- 7, Нью-Йорк 1956-1961.

Ермаков П.Ю., Агапит (Борзаковский Антоний Иосифович), [в:] Православная энциклопедия, т. 1, Москва 2000, с. 226227.

К пятилетию архипастырского служения преосвященнейшего Агапита, епископа Екатеринославского и Мариупольского, в Екатеринославской епархии, Екатеринослав 1916.

Ю. А. Лабынцев, Алексий (Громадский Александр Якубович), [в:] Православная энииклопедия, т. 1, Москва 2000, с. 664665.

Мануил (Лемешевский В.В.), митр., Русские православные иерархи периода с 1893 по 1965 г2. (включительно), Erlangen 1979-1989, т. 1.

Мартиролог расстрелянных и захороненных на полигоне НКВД „Объект Бутово” 08.08.1937-19.10.1938, Москва 1997. 
М. Польский, протопресв. Новые мученики Российские, Москва 1994, ч. 1, с. 178; ч. 2.

И. Резникова, Православие на Соловках: Материаль по истории Соловеикого лагеря, Санкт-Петербург 1994.

Синодик пострадавщих за веру и Церковь Христову в Бутово, Москва 1995.

Состав Святейтего Правительствующего Синода и Российской иерковной иерархии на 1917 год, Петроград 1917.
В. Цыпин, прот., Арсений (Смоленеи Александр Владиславович), [в:] Православная энииклопедия, т. 3, Москва 2002, с. 408-409.

В. Цыпин, прот., История Русской Церкви, 1917-1997, т. 9, Москва 1997.

Шумилов Е. Ф., Православная Удмуртия: История Ижевской и Удмуртской епархии, ХХ в., Ижевск 1996.

Э.П.Р., Антоний (Храповицкий Алексей Павлович), [в:] Православная энииклопедия, т. 2, Москва 2001, с. 646-652.

Rozmiar artykułu: 1 arkusz wydawniczy 